\title{
GEOGRAPHIC DISTRIBUTION OF TWINHORN BLENNY, CORALLIOZETUS CARDONAE (ACTINOPTERYGII: PERCIFORMES: CHAENOPSIDAE), WITH NEW RECORDS FROM THE SOUTHERN CARIBBEAN
}

\author{
Oscar LASSO-ALCALÁ ${ }^{1 *}$, Juan POSADA ${ }^{2}$, James VAN TASSELL ${ }^{3}$, D. Ross ROBERTSON ${ }^{4}$, \\ and Angel FARIÑA ${ }^{5}$ \\ ${ }^{1}$ Museo de Historia Natural La Salle, Fundación La Salle de Ciencias Naturales, Venezuela \\ ${ }^{2}$ Department of Biology Organisms, Universidad Simon Bolivar, Venezuela \\ ${ }^{3}$ Department of Biology, Hofstra University, USA \\ ${ }^{4}$ Smithsonian Tropical Research Institute, Panamá \\ ${ }^{5}$ Department of Biology, Universidad de Oriente, Venezuela
}

Lasso-Alcalá O., Posada J., Van Tassell J., Robertson D.R., Fariña A. 2012. Geographic distribution of twinhorn blenny, Coralliozetus cardonae (Actinopterygii: Perciformes: Chaenopsidae), with new records from the southern Caribbean. Acta Ichthyol. Piscat. 42 (1): 59-64.

\begin{abstract}
The twinhorn blenny, Coralliozetus cardonae Evermann et Marsh, 1899, is currently known from the Caribbean Sea and adjacent waters, with the exception of the Gulf of Mexico, Florida, Bermuda, and the coast and islands to the north of Venezuela. In this work we report for the first time its occurrence at 19 stations from the Venezuelan coast, Curaçao, and Bonaire Island (Netherlands Antilles), in the Southern Caribbean, based on the examination of 155 specimens. In addition, we provide information on the meristic, distinctive characters, and habitat of this species.
\end{abstract}

Keywords: Tubeblennies, Coralliozetus cardonae, new records, Venezuela, Netherlands Antilles, south-east Caribbean Sea

The fishes representing the genus Coralliozetus Evermann et Marsh, 1899 inhabit reefs and rocky shores in shallow trans-isthmian tropical marine waters. They are characterized by the absence of lateral line, dorsal fin with 28 to 31 elements, one or two pairs of simple supra-orbital cirri. When two pairs are present, the rear cirrus is small and the front cirrus larger, sometimes larger than the diameter of the eye (Stephens 1963, Stephens et al. 1966, Acero 1984, Hastings 1997, Williams 2003). This genus is represented by six species, five present in the Tropical Eastern Pacific - C. angelicus (Böhlke et Mead, 1957); C. boehlkei Stephens, 1963; C. rosenblatti Stephens, 1963; C. micropes (Beebe et Tee-Van, 1938); and C. springeri Stephens et Johnson, 1966-and one in the Atlantic - C. cardonae Evermann et Marsh, 1899 (see: Stephens 1963, Acero 1984, Hastings 1997, Hastings 2000, Williams 2003).

The twinhorn blenny, Coralliozetus cardonae, is apparently endemic to the Caribbean Sea and the Bahamas, but is not known from the Gulf of Mexico (Fig. 1), Florida, and Bermuda. Its confirmed localities are listed below along with the important data. The records from collections of several museums in the USA (USNM, UF, ANSP, AMNH, SIO) and Colombia (MHNM-INVEMAR) are included. Known previously from the type locality: Cayo Cardona, Playa de Ponce and Guanica in Puerto Rico, and the following localities: the Bahamas (Salt, Sandy, Silver, and Exuma Cays), Cayman (Grand Cayman), Navassa (Northwest point, Northcentral coast, Lulu Bay), Virgin Islands (Saint John), Saint Bartelemy (Fourche Island, isletes Syndare, Port of Gustavia), Dominica (Mero, Grand and Prince Rupert Bays), Saint Lucia (Port Castries, Vide Bouteille, Vigie point, Pigeon Island, Soufreire), Grenada (Saint George Harbor, Martins Bay), Tobago (Bloody and Brisant Bay, Charlotteville, Little Tobago Island), Curaçao (Cornelisbaai, Fuikbaai), coasts of Belize (Pelican Cays), Panamá (Bahía Azul), and Colombia (Bahía de Santa Marta, Punta de la Aguja) (Evermann and Marsh 1899, Stephens 1963, Stephens et al. 1966, Nagelkerken 1974, Greenfield and Johnson 1981, Acero 1984, 1987, Böhlke and Chaplin 1993, Smith 1997, Hastings and Robertson 1999, Ramjohn 1999, Collette et al. 2003, Smith et al. 2003). A record from Cuba (Claro and Parenti 2001) requires confirmation, because no spec-

\footnotetext{
${ }^{*}$ Correspondence: Dr. Oscar Lasso-Alcalá. Museo de Historia Natural La Salle, Fundación La Salle de Ciencias Naturales. Apartado Postal 1930, Caracas 1010-A,
} Venezuela, phone: + 58212 7095872, fax: + 58212 7095871, e-mail: oscar.lasso1@fundacionlasalle.org.ve/oscar.lasso@gmail.com. 
imens were deposited in a museum (Rodolfo Claro, personal communication).

In this paper we present data on new records of Coralliozetus cardonae from the continental coast and islands off northern Venezuela, and the Netherlands Antilles (Curaçao and Bonaire Island), in the South-eastern Caribbean (Fig. 1).

Recently, from 2005 to 2009 , we made six expeditions to collect fishes along the coast and islands of Venezuela, where we sampled 145 sites using small rotenone stations, mostly during scuba dives (Projects: Shore Fishes of the Great Caribbean and Electronic Guide of the Marine Fishes of Venezuela). During those expeditions we collected 149 specimens of Coralliozetus cardonae (Fig. 2) in 14 stations (see material examined and Fig. 1). The specimens collected were deposited at the Museo de Historia Natural La Salle (MHNLS), Caracas, Venezuela, and the American Museum of Natural History (AMNH), New York, USA. In addition we also examined four specimens collected by D.R.R. and J.V.T. at Curaçao Island (February 2005), where there were no previous records, and two specimens collected at a station at Bonaire Island (August 2001) (Netherlands Antilles) and deposited in the National Museum of Natural History, Smithsonian Institution (USNM), Washington, USA.

Standard length (SL) was measured to the nearest 0.01 $\mathrm{mm}$ by digital calipers and meristic counts were made using a reflected light based stereomicroscope. To identify the specimens we used the original description (Evermann and Marsh 1899), other descriptive works (Stephens et al. 1966, Acero 1987, Hastings 1997, Hastings and Robertson 1999), and taxonomic keys (Stephens 1963, Williams 2003). Abbreviations of institutions follow Leviton et al. (1985), with the addition of Museo de Historia Natural La Salle (MHNLS), Caracas,

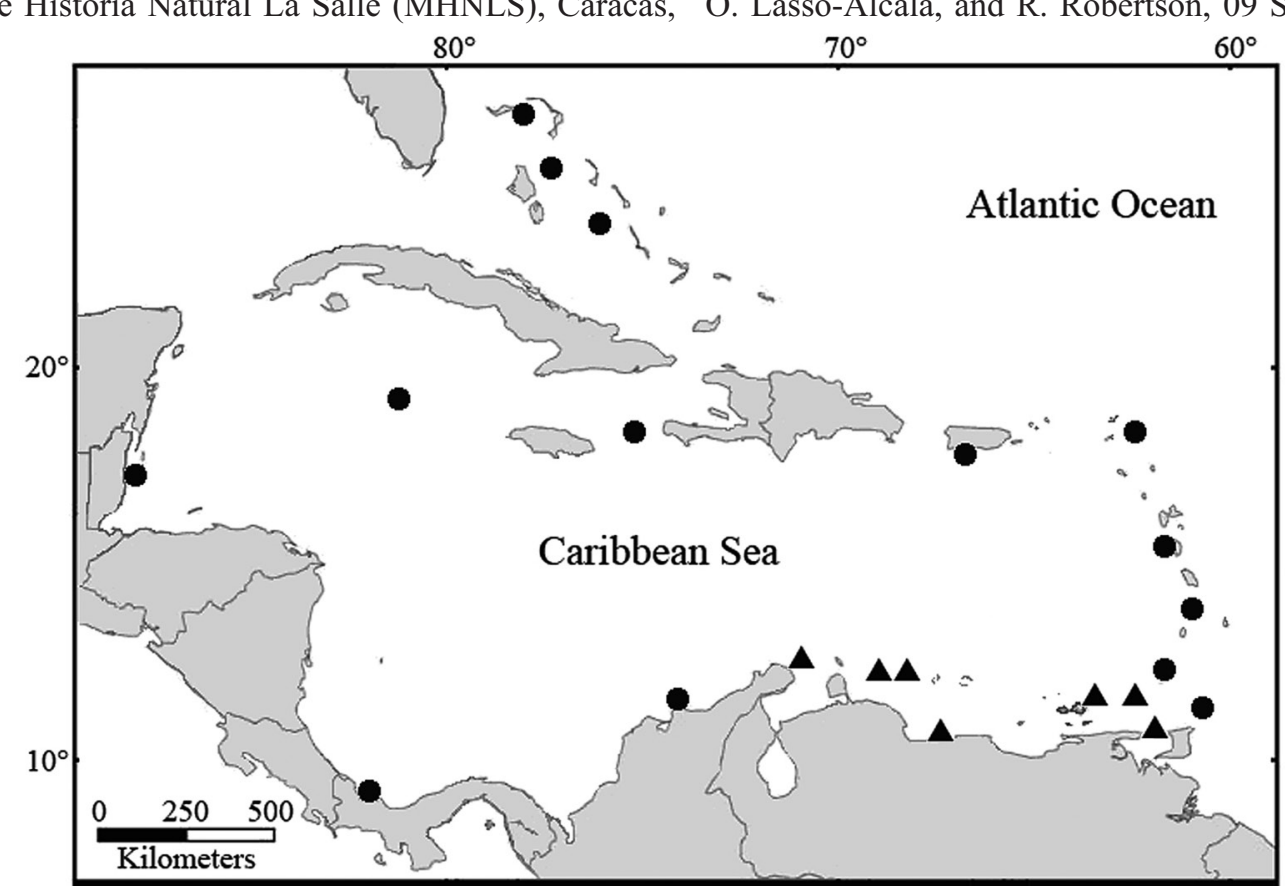

Fig. 1. Distribution of Coralliozetus cardonae. Circles: previous records; triangles: new records (see material examined); Individual symbols may indicate more than one locality
Venezuela, and the Museo de Historia Natural Marina, Instituto de Investigaciones Marinas y Costeras (MHNMINVEMAR), Santa Marta, Colombia.

Material examined (new records). We examined a total 26 lots that included 155 specimens (72 males, 71 females, and 12 juveniles), from the following 19 localities.

Venezuela: MHNLS 24600, 5 males (21.78-18.81 mm SL), Puerto Real, Archipiélago de Los Frailes, Dependencias Federales, northeast Isla de Margarita $\left(11^{\circ} 12^{\prime} 11.4^{\prime \prime} \mathrm{N}\right.$ $\left.64^{\circ} 15^{\prime} 38.04^{\prime \prime} \mathrm{W}\right), 5 \mathrm{~m}$, J. Van Tassell, R. Robertson, J. Posada, and L. Rocha, 24 September 2005. MHNLS 24601, male (20.02 mm SL), northwest of La Iguana, Archipiélago de Los Testigos, Dependencias Federales $\left(11^{\circ} 21^{\prime} 37.69^{\prime \prime} \mathrm{N} 64^{\circ} 51^{\prime} 41.11^{\prime \prime} \mathrm{W}\right), 11 \mathrm{~m}, \mathrm{~J}$. Van Tassell, R. Robertson, and J. Posada, 05 September 2006. MHNLS 24602, 10 males (21.76-19.51 mm SL) and female (18 mm SL), north end of Cayo Nordeste, Archipiélago de Los Testigos, Dependencias Federales $\left(11^{\circ} 24^{\prime} 45.18^{\prime \prime} \mathrm{N} 64^{\circ} 57^{\prime} 9.9^{\prime \prime} \mathrm{W}\right), 9 \mathrm{~m}, \mathrm{~J}$. Van Tassell, R. Robertson, and J. Posada, 07 September 2006. MHNLS 24603, 8 females (21.79-18.18 mm SL), 3 males (19.26-18.18 mm SL), and one juvenile (9.68 mm SL), La Cienaga, West of Ocumare de la Costa, Aragua State, Venezuela $\left(10^{\circ} 29^{\prime} 18.06^{\prime \prime} \mathrm{N} 68^{\circ} 11^{\prime} 48.08^{\prime \prime} \mathrm{W}\right), 0-1 \mathrm{~m}$, J. Van Tassell, R. Robertson, and J. Posada, 24 July 2007.

MHNLS 24604, 10 females (19.72-16.22 mm SL), 8 males (23.87-21.58 mm SL), and 7 juveniles (10.89-9.47 mm SL), Puerto Nuevo, artificial Bay, Monje del Sur, Archipiélago de Los Monjes, Dependencias Federales $\left(12^{\circ} 21^{\prime} 38.20^{\prime \prime} \mathrm{N} 71^{\circ} 05^{\prime} 49.45^{\prime \prime} \mathrm{W}\right), 0-2 \mathrm{~m}$, J. Posada, O. Lasso-Alcalá, and R. Robertson, 08 September 2008. MHNLS 24605, male (17.12 mm SL), Monje del Norte, Archipiélago de Los Monjes, Dependencias Federales $\left(12^{\circ} 29^{\prime} 0.89^{\prime \prime} \mathrm{N} 71^{\circ} 05^{\prime} 2.44^{\prime \prime} \mathrm{W}\right), \quad 0-2 \mathrm{~m}, \quad J$. Posada, O. Lasso-Alcalá, and R. Robertson, 09 September 2008.

\section{$60^{\circ}$}


MHNLS 24606, 4 females (18.70-11.46 mm SL), 3 males (22.73-19.45 mm SL), and juvenile (10.22 mm SL), Natural Bay, Military Base, Monje del Sur, Archipiélago de Los Monjes, Dependencias Federales $\left(12^{\circ} 21^{\prime} 34.81^{\prime \prime} \mathrm{N}\right.$ $\left.71^{\circ} 05^{\prime} 45.31^{\prime \prime} \mathrm{W}\right), 0-3 \mathrm{~m}$ depth, J. Posada, O. LassoAlcalá, and R. Robertson, 11 September 2008. MHNLS 24607, 3 females (17.81-11.55 mm SL) and 2 males (19.48-18.69 mm SL), Isla de Patos, east of Ensenada Puerto de Tablas, Dependencias Federales, northwest Golfo de Paria $\left(10^{\circ} 38^{\prime} 8.92^{\prime \prime} \mathrm{N} 62^{\circ} 07^{\prime} 49.01^{\prime \prime} \mathrm{W}\right), 0-5 \mathrm{~m}$, J. Posada, O. Lasso-Alcalá, R. Robertson, and J. Van Tassell, 1 December 2008. MHNLS 24608, 3 males (22.10-20.60 mm SL) and female (13.03 mm SL), Isla de Patos, entrance of the cave, Dependencias Federales, northwest Golfo de Paria $\left(10^{\circ} 38^{\prime} 10.72^{\prime \prime} \mathrm{N} 62^{\circ} 07^{\prime} 38.24^{\prime \prime} \mathrm{W}\right)$, 0-6 m depth, J. Posada, O. Lasso-Alcalá, R. Robertson, and J. Van Tassell, 1 December 2008. MHNLS 24609, 3 females (17.78-13.44 mm SL) and 2 males (20.35-19.98 mm SL), Isla de Patos; little bay beside the cave, Dependencias Federales, northwest Golfo de Paria $\left(10^{\circ} 38^{\prime} 11.72^{\prime \prime} \mathrm{N} 62^{\circ} 07^{\prime} 39.29^{\prime \prime}\right), 0-5 \mathrm{~m}, \mathrm{~J}$. Posada, O. Lasso-Alcalá, R. Robertson, and J. Van Tassell, 1 December 2008. MHNLS 24610, 19 males (28.84-17.30 mm SL), 13 females (23.59-14.20 mm SL), and 2 juveniles (10.18-10.45 mm SL), Promontorio de Paria, east of Punta Narizona, southern coast of Península de Paria, Sucre State $\left(10^{\circ} 43^{\prime} 56.14^{\prime \prime} \mathrm{N} 62^{\circ} 08^{\prime} 35.23^{\prime \prime} \mathrm{W}\right)$, 0-3 m, J. Posada, O. Lasso-Alcalá, R. Robertson, and J. Van Tassell, 2 December 2008. MHNLS 24611, male (24.21 mm SL), Promontorio de Paria, west of Punta Narizona, south coast of Península de Paria, Sucre State $\left(10^{\circ} 43^{\prime} 53.18^{\prime \prime} \mathrm{N} 62^{\circ} 08^{\prime} 15.15^{\prime \prime} \mathrm{W}\right), 0-4 \mathrm{~m}, \mathrm{~J}$. Posada,
O. Lasso-Alcalá, R. Robertson, and J. Van Tassell, 2 December 2008. MHNLS 24612, 5 females (18.40-15.53 mm SL) and male (19.31 mm SL), Ensenada San Francisco, north coast of Península de Paria, Sucre State $\left(10^{\circ} 42^{\prime} 43.56^{\prime \prime} \mathrm{N} 63^{\circ} 59^{\prime} 44.66^{\prime \prime} \mathrm{W}\right), 0-6 \mathrm{~m}$, J. Posada, O. Lasso-Alcalá, R. Robertson, and J. Van Tassell on 3 December 2008. MHNLS 24613, 18 females (20.43-12.15 mm SL), 11 males (23.59-14.20 mm SL), and juvenile (10.18 mm SL), Hueco del Indio, Promontorio de Paria, south coast of Península de Paria, Sucre state $\left(10^{\circ} 44^{\prime} 0,89^{\prime \prime} \mathrm{N} 62^{\circ} 09^{\prime} 0,65 \mathrm{~W}\right), 1-4 \mathrm{~m}$, J. Posada, O. LassoAlcalá, R. Robertson, and J. Van Tassell, 4 December 2008. MHNLS 24614, male (23.82 mm SL), Bahía Cereza, Obispo del Sur, south coast of Península de Paria, Sucre State $\left(10^{\circ} 43^{\prime} 27^{\prime \prime} \mathrm{N} 62^{\circ} 07^{\prime} 39.59^{\prime \prime} \mathrm{W}\right), 0-4 \mathrm{~m}$, J. Posada, O. Lasso-Alcalá, R. Robertson, and J. Van Tassell, 4 December 2008. AMNH 237330, male (22.53 mm SL), Puerto Real, Archipiélago de Los Frailes, Dependencias Federales, northeast Isla de Margarita $\left(11^{\circ} 12^{\prime} 11.40^{\prime \prime} \mathrm{N}\right.$ $\left.63^{\circ} 44^{\prime} 25.92^{\prime \prime} \mathrm{W}\right), 7 \mathrm{~m}$, J. Van Tassell, R. Robertson, J. Posada, and L. Rocha, 24 September 2005. AMNH 247631, male (16.08 mm SL), north of Cayo Nordeste, Archipiélago de Los Testigos, Dependencias Federales $\left(11^{\circ} 24^{\prime} 45.18^{\prime \prime} \mathrm{N} 63^{\circ} 2^{\prime} 50.10 \mathrm{~W}\right), 9 \mathrm{~m}, \mathrm{~J}$. Van Tassell, R. Robertson, and J. Posada, 07 September 2006. AMNH 248186, 2 males. (20.14-19.11 mm SL), northwest of La Iguana, Archipiélago de Los Testigos, Dependencias Federales $\left(11^{\circ} 21^{\prime} 37.69^{\prime \prime} \mathrm{N} 63^{\circ} 8^{\prime} 18.89^{\prime \prime} \mathrm{W}\right), 11 \mathrm{~m}$, J. Van Tassell, R. Robertson, and J. Posada, 05 September 2006. AMNH 249116, male (18.95 mm SL), Isla de Patos; little bay beside the cave, Dependencias Federales, nortwest Golfo de Paria $\left(10^{\circ} 38^{\prime} 11.72^{\prime \prime} \mathrm{N} 61^{\circ} 52^{\prime} 20.71^{\prime \prime} \mathrm{W}\right), 0-5 \mathrm{~m}$, J. Posada,



Fig. 2. Specimens recently collected of Coralliozetus cardonae in the Golfo de Paria, Venezuela, (a) adult male AMNH 249116 (19.95 mm SL) from Isla de Patos, northwest Golfo de Paria, and (b) adult female AMNH 249117 (19.44 mm SL) from Promontorio de Paria, south coast of Península de Paria; Photos by J. Van Tassell 
O. Lasso-Alcalá, R. Robertson, and J. Van Tassell, 1 December 2008. AMNH 249117, 2 females (19.44-20.38 mm SL), Promontorio de Paria, east of Punta Narizona, south coast of Península de Paria, Sucre State (1043'56.14"N 61²1'24.77”W), 0-3 m, J. Posada, O. LassoAlcalá, R. Robertson, and J. Van Tassell, 2 December 2008. AMNH 249118, male (24.87 mm SL), Bahía Cereza, Obispo del Sur, south coast of Península de Paria, Sucre State (10 43'27.62'N 61 $\left.52^{\circ} 20.42^{\prime \prime} \mathrm{W}\right), 0-4$ m, J. Posada, O. LassoAlcalá, R. Robertson, and J. Van Tassell, 4 December 2008.

Bonaire Island: USNM 366211, 2 males (23.30-21.20 mm SL), Tori's Reef, southwest Shore of Bonaire Island, Netherlands Antilles (12 $\left.04^{\prime} 10^{\prime \prime} \mathrm{N} 68^{\circ} 16^{\prime} 51^{\prime \prime} \mathrm{W}\right)$, 0-1 m, L. Wilk and collaborators 1 August 2001.

Curaçao Island: AMNH 239008, male (18.23 mm SL), Hundu beach, northwest coast, Curaçao Island, Netherlands Antilles (12 $\left.{ }^{\circ} 15^{\prime} 37.02^{\prime \prime} \mathrm{N} 69^{\circ} 7^{\prime} 11.28^{\prime \prime} \mathrm{W}\right)$, no depth recorded, J. Van Tassell, R. Robertson, and S. Piontek, 8 February 2005. AMNH 243318, female (16.69 mm SL), Janthiel, southwest coast, Curaçao Island, Netherlands Antilles (12 $\left.{ }^{\circ} 4^{\prime} 44.82^{\prime \prime} \mathrm{N} 68^{\circ} 53^{\prime} 16.32^{\prime \prime} \mathrm{W}\right)$ no depth recorded, J. Van Tassell, R. Robertson, S. Piontek, and A. Kramer, 04 February 2005. AMNH 239022, male (18.99 mm SL), Water Factory, Curaçao Island, Netherlands Antilles ( $\left.12^{\circ} 6^{\prime} 31.14^{\prime \prime} \mathrm{N} 68^{\circ} 57^{\prime} 2.22^{\prime \prime} \mathrm{W}\right), 0-4 \mathrm{~m}$, J. Van Tassell, R. Robertson, S. Piontek, A. Kramer, and
J. Schrier, 08 February 2005. AMNH 238843, male (10.53 $\mathrm{mm}$ SL), southwest coast, Curaçao Island, Netherlands Antilles $\left(12^{\circ} 5^{\prime} 1.38^{\prime \prime} \mathrm{N} 68^{\circ} 53^{\prime} 47.22^{\prime \prime} \mathrm{W}\right), 1-12 \mathrm{~m}$, J. Van Tassell, R. Robertson, and A. Kramer, 02 February 2005.

Description and distinctive characters. Coralliozetus species have the following characteristics: (i) They are small in size, with a maximum length of $\sim 37 \mathrm{~mm} \mathrm{SL}$ in C. micropes (see: Stephens 1963), in C. cardonae with a maximum length record of $\sim 25 \mathrm{~mm}$ SL (Acero 1987). The largest specimen of $C$. cardonae that we examined is a male $28.84 \mathrm{~mm}$ SL (MHNLS 24610). (ii) The presence and variations in the form of supraorbital cirri differentiate the genera of Atlantic Chaenopsidae (Stephens 1963, Stephens et al. 1966, Acero 1984, Hastings 1997, Williams 2003). Coralliozetus species have one or two pairs of simple, non-branching supraorbital cirri, originating over the centre of the top of each eye. In C. rosenblat$t i$ is present a flaplike supraorbital cirrus. In C. cardonae there are two pairs of ocular cirri; the anterior most cirri are larger, up to longer than the ocular diameter in males and shorter in females, and the rear cirri smaller in both sexes. (iii) The dorsal fin of Coralliozetus species has 28-33 elements. In $C$ cardonae the dorsal fin has XVI-XIX spines, and 11 to 13 soft rays, for a total of 28 to 32 elements. (iv) Distinct flag-like membrane sometimes on anterior edge of dorsal first spine in males.

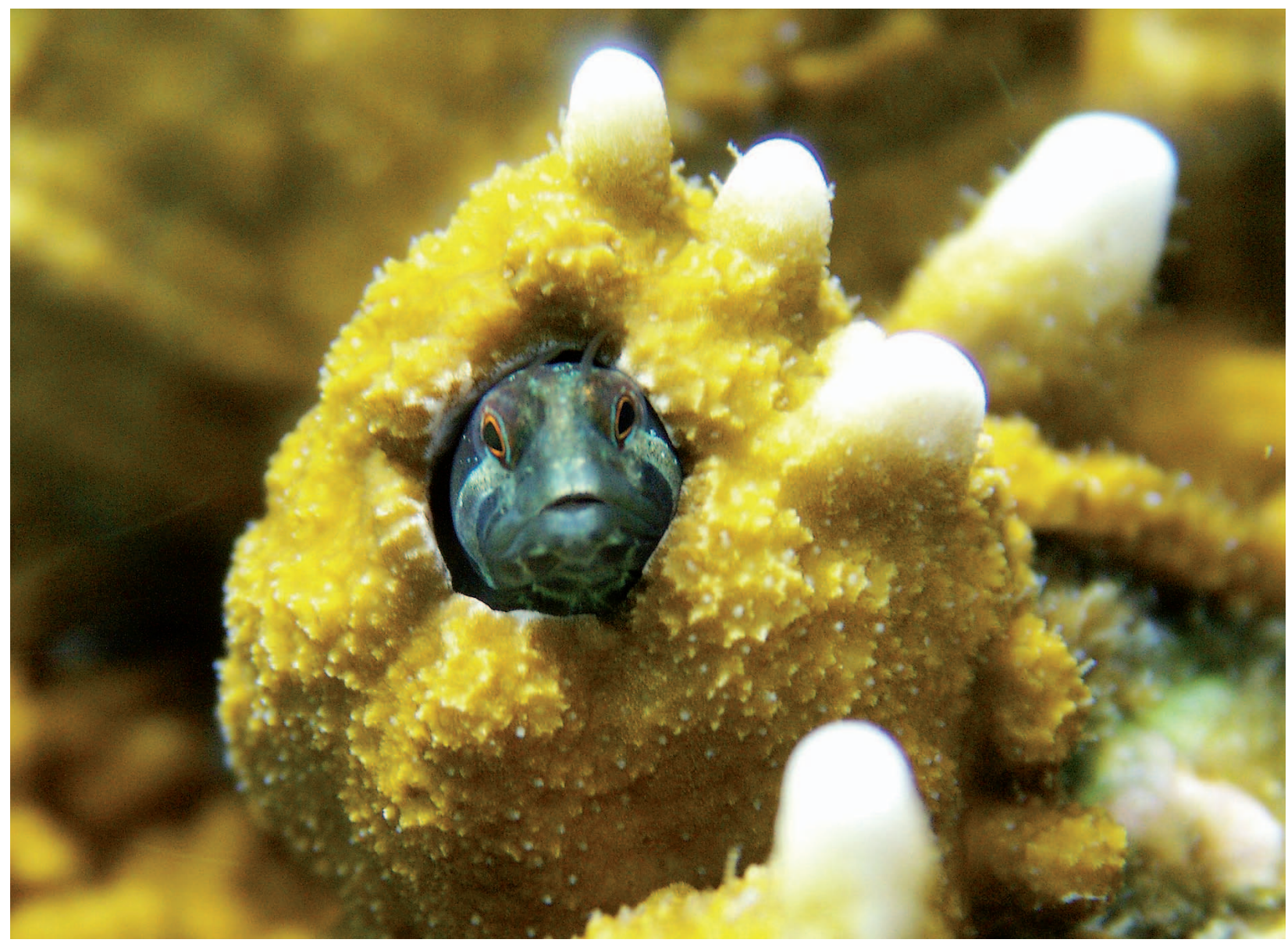

Fig. 3. Male of Coralliozetus cardonae inhabiting tubes previously occupied by spiral-gilled worm Spirobranchus spp., surrounded by the fire coral (Hydrozoan) Millepora alcicornis, in south coast of Península de Paria, Venezuela; Photo by Angel Fariña 
Table 1

Dorsal- and anal-fin ray counts of Coralliozetus cardonae from coast and islands of Venezuela, Curaçao, and Bonaire islands $(n=155)$

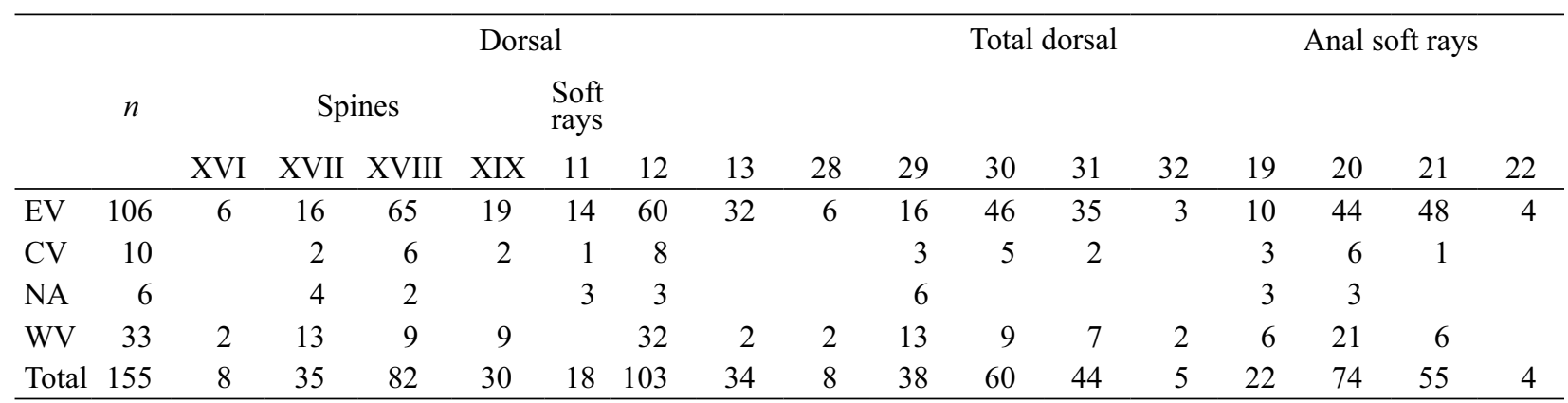

$\mathrm{EV}=$ Eastern Venezuela (Paria, Testigos, Frailes); $\mathrm{CV}=$ Central Venezuela (La ciénaga); NA = Netherlands Antilles (Curaçao, Bonaire); WV = Western Venezuela (Monjes).

There is as small projection on the front surface of the middle and top of the first spine. (v) The anal fin of C. cardonae has II spines and 19-22 soft rays. (vi) As is typical for the genus, the pectoral fin of all 155 specimens had 13 rays. Table 1 presents meristic data for all specimens examined in this study. Our data suggest a possible geographic variation in fin-ray counts from east to west along the coast and islands to the north of Venezuela. This decrease was also observed in Panamá (Hastings and Robertson 1999) and Belize (Greenfield and Johnson 1981) specimens, that presented minors modes in the dorsal soft rays (11) and anal soft rays (19), than in the Venezuelan and Netherlands Antilles specimens. However, populations of the northern Caribbean (Bahamas, Puerto Rico and Saint John) (Stephens et al. 1966), and Colombia (Acero 1987), present equal mode in the counts of the spines (18) and total elements of the dorsal fin (30), as those observed in our specimens from the east and central coast of Venezuela. (vii) The colour pattern is well differentiated between males and females (Fig. 2). Males: the head and front third of the body are blackish, heavily stippled with fine blue spots, the rear body is transparent, with dark vertebral column and spines, dark marks along the bases of the dorsal and anal fins; a distinctive oblique whitish, blue-edged bar runs from the eye down and back towards the centre of the operculum; five whitish bars on and under the lower jaw; iris red, with a thin blue-white ring around it; supraorbital cirri black; spinous dorsal fin black at front, with small blue-white spots, shading to grey at rear; soft dorsal fin and anal fin translucent, with sooty cast, outer edges yellowish, rays dark; tail fin translucent with dark rays. Females: head and body transparent, irregular brown spots and blotches on head and front third of body, rear body coloured as in male; a large, indistinct whitish blotch in the cheek immediately behind eye, five dark bars on branchiostegal membrane and lower jaw; dorsal and anal fins transparent, with yellowish edges, fin spines and rays dark; first three dorsal fin spines orangeyellow; caudal fin translucent, with dark rays.

Apparent geographic variation in male colours: photographs of what evidently is $C$. cardonae from Mona island (Puerto Rico) presented by Reefnet (Anonymous 2007) show a very different color pattern to the males of specimens we collected, and males of C. cardonae from Bonaire island and Utila (Honduras) that are also presented by Reefnet (Anonymous 2007). In Puerto Rican males the upper head and top half of the eye-balls are bright red, and the membranes spanning the first three spines of the dorsal fin are bluish white. Two photographs of a male from Saint Vincent in Reefnet (Anonymous 2007) show a brownish head and whitish front of the dorsal fin.

Habitat. According with various authors (Böhlke and Chaplin 1993, Greenfield and Johnson 1981, Acero 1987, Hastings and Robertson 1999), C. cardonae occurs in clear-water habitats, from immediately below the intertidal to $\sim 5 \mathrm{~m}$ depth. Most specimens deposited in museums (USNM, UF, ANSP, AMNH, MHNM-INVEMAR) and examined by us, were captured within this depth range, although at Archipelago de Los Testigos, Venezuela (MHNLS 24601, 24602) 10 specimens were captured from 9 to $11 \mathrm{~m}$. As in the coasts of Curaçao (Nagelkerken 1974), Colombia (Acero 1987) and Saint Lucia (Hastings and Robertson 1999), we found that in Venezuela C. cardonae is associated with hard coral and rocky bottoms. In such habitat it is very abundant in some stations in the Península de Paria (Fig. 3, MHNLS 24610, 24613: 64 specimens) and Archipiélago de Los Monjes (MHNLS 24604: 25 specimens). There it inhabits empty worm tubes and empty barnacle tests, often imbedded in fire coral (Hydrozoan) Millepora alcicornis (see Fig. 3).

\section{ACKNOWLEDGEMENTS}

We thank to Arturo Acero (Universidad Nacional de Colombia, sede Caribe), Jeff Williams (Smithsonian Institution), and Cesar Barrio-Amorós (Fundación Andígena) for reviews of earlier version of the manuscript. Jeff Williams, Sandra Raredon (USNM), Robert Robins, George Burgess (UF), Marck Sabaj, John Lundberg (ANSP), Luz Marina Mejía-Ladino, Gabriel Navas (MHNM-INVEMAR), Scott Schaefer and Melany Stiassny (AMNH) kindly offered data of Coralliozetus cardonae in their collections. We thank the Instituto Socialista de la Pesca y Acuicultura (INSOPESCA), Venezuela, for scientific collecting permits. 


\section{REFERENCES}

Acero A.P. 1984. The chaenopsine blennies of the southwestern Caribbean (Pisces, Clinidae, Chaenopsinae). I. Systematic analysis and zoogeography. Anales del Instituto de Investigaciones Marinas de Punta de Betín 14: 29-46.

Acero A.P. 1987. The chaenopsine blennies of the southwestern Caribbean (Pisces, Clinidae, Chaenopsinae). III. The genera Chaenopsis and Coralliozetus. Boletín Ecotropicos 16: 1-21.

Anonymous 2007. Reef fish identification: Florida, Caribbean, Bahamas. 4th edn. ReefNet Inc. www.reefnet.ca

Böhlke J.E., Chaplin C.G. 1993. Fishes of the Bahamas and adjacent tropical waters. 2nd edn. University of Texas Press, Austin, TX, USA.

Claro R., Parenti L.R. 2001 The marine ichthyofauna of Cuba. Pp. 21-57. In: Claro R., Lindeman K.C., Parenti L.R. (eds.). Ecology of the marine fishes of Cuba. Smithsonian Institution Press, Washington and London.

Collette B.B., Williams J.T., Thacker C.E., Smith M.L. 2003. Shore fishes of Navassa Island, West Indies: a case study on the need for rotenone sampling in reef fish biodiversity studies. Aqua 6 (3): 89-131.

Evermann B.W., Marsh M.C. 1899. Descriptions of new genera and species of fishes from Puerto Rico. Report of the United States Fish Commission 25: 351-362.

Greenfield D.W., Johnson R.K. 1981. The blennioid fishes of Belize and Honduras, Central America, with comments on their systematics, ecology, and distribution (Blenniidae, Chaenopsidae, Labrisomidae, Tripterygiidae). Fieldiana Zoology (New Series) No. 8: 1-106.

Hastings P.A. 1997. Phylogenetic relationships of the Coralliozetus clade of chaenopsid blennies, with description of a new genus (Teleostei, Blennioidei). Bulletin of Marine Science 61 (3): 743-761.

Hastings P.A. 2000. Biogeography of the Tropical Eastern Pacific: distribution and phylogeny of chaenopsid fishes. Zoological Journal of the Linnean Society 128 (3): 319-335. DOI: 10.1111/j.1096-3642.2000.tb00166.x

Hastings P.A., Robertson D.R. 1999. Notes on a collection of chaenopsid blennies from Bahia Azul, Bocas del Toro, Caribbean, Panama. Revue Française d'Aquariologie 26 (1-2): 33-38.
Leviton A.E., Gibbs R.H.jr., Heal E., Dawson C.E. 1985. Standards in herpetology and ichthyology: Part I. Standard symbolic codes for institutional resource collections in herpetology and ichthyology. Copeia 1985 (3): 802-832.

Nagelkerken W.P. 1974. On the occurrence of fishes in relation to corals in Curaçao. Studies on the Fauna of Curaçao and Other Caribbean Islands 45: 118-141.

Ramjohn D.D. 1999. Checklist of coastal and marine fishes of Trinidad and Tobago. Marine Fishery Analysis Unit, Fisheries Division, Ministry of Agriculture, Land and Marine Resources, Trinidad and Tobago. Fisheries Information Series 8.

Smith C. 1997. National Audubon Society field guide to tropical marine fishes of the Caribbean, the Gulf of Mexico, Florida, the Bahamas, and Bermuda. Alfred A. Knopf, Inc., New York.

Smith C.L., Tyler J.C., Davis W.P., Jones R.S., Smith D.G., Baldwin C.C. 2003. Fishes of the Pelican Cays, Belize. Atoll Research Bulletin No. 497.

Stephens J.S.jr. 1963. A revised classification of the blennioid fishes of the American family Chaenopsidae. University of California Publications in Zoology 68: 1-165.

Stephens J.S.jr., Hobson E.S., Johnson R.K. 1966. Notes on distribution, behaviour, and morphological variation in some chaenopsid fishes from the tropical eastern Pacific, with descriptions of two new species, Acanthemblemaria castroi and Coralliozetus springeri. Copeia 1966 (3): 424-438.

Williams J. 2003. Chaenopsidae. Pp. 1761-1767. In: Carpenter K. (ed.). The living marine resources of the Western Central Atlantic. Vol. 3: Bony fishes part 2 (Opistognathidae to Molidae). FAO species identification guide for fishery purposes. American Society of Ichthyologists and Herpetologists. FAO, Rome. Special Publication No. 5.

Received: 19 August 2011

Accepted: 6 December 2011

Published electronically: 31 March 2012 